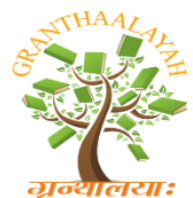

\author{
INTERNATIONAL JOURNAL OF RE
GRANTHAALAYAH \\ A knowledge Repository
}

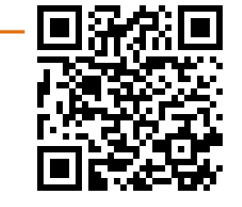

Science

\title{
RATS TRAPPING AT DIFFERENT TYPES OF LOCATION IN LIWA BOTANICAL GARDEN, LAMPUNG, INDONESIA
}

\author{
Bernice Rizki Novera $^{* 1}$, M. Kanedi ${ }^{1}$, Nuning Nurcahyani ${ }^{1}$, Sutyarso ${ }^{1}$ \\ ${ }^{1}$ Department of Biology, Faculty of Mathematics and Sciences, University of Lampung, Bandar \\ Lampung, Indonesia
}

\begin{abstract}
Motivation/Background: Rat is cosmopolitan animal which means they can live in all type of places worldwide, including highlands, lowlands, rice fields, forests, and settlements. A high rat population can have an impact on losses in various fields of human life. The Liwa Botanical Garden is one of the areas developed for tourism so the presence of rats is important to note.

Method: This study aims to determine the success rate of rat catching in Liwa Botanical Garden by different type of trapping location, namely bamboo groves, houses, river banks, and gardens. The traps were set every day for 10 days. The observations included the number of individual, the type of rat, sex and size of the trapped mice. All the data obtained were analyzed descriptively.

Results: The live trapping resulted in 11 individuals of small mammals belongs to three species namely Rattus exultant, Hylomys suillus and Suncus murinus. Among the four trapping location, bamboo groves is the place that catches the most, and the females were trapped more than the males.
\end{abstract}

Keywords: Liwa Botanical Gardenp; Lampung; Rat Traps; Live Traps.

Cite This Article: Bernice Rizki Novera, M. Kanedi, Nuning Nurcahyani, and Sutyarso. (2020). "RATS TRAPPING AT DIFFERENT TYPES OF LOCATION IN LIWA BOTANICAL GARDEN, LAMPUNG, INDONESIA." International Journal of Research - Granthaalayah, 8(1), 237-242. https://doi.org/10.29121/granthaalayah.v8.i1.2020.276.

\section{Introduction}

Liwa Botanical Garden is a recreational and educational facility for the community, especially in Lampung Province. In this area, there are many types of animals, one of which is a mammal which is a mouse. The Liwa Botanical Garden does not yet have much data about the types of animals in it, especially mice. Rats are cosmopolitan animals which means they can live in all places such as in the highlands, lowlands, rice fields, forests, and settlements. So it is suspected that the Liwa Botanical Garden will also find mice. A high rat population can have an impact on losses in various fields of human life. mouse traps using a single live trap are practical and safe traps for the environment. 
Environmental factors can affect several aspects such as human welfare and disease aspects. In some cases, the tendency for the disease is influenced by poor physical and biological environmental conditions or certain organisms to multiply. Rats are cosmopolitan animals which means they can live in all places such as in the highlands, lowlands, rice fields, forests, beaches and settlements [1].

Human life is often associated with wild animals such as mice. High rat population can have an impact on losses in various fields of human life, such as in the field of rat settlement can cause damage to residential buildings, offices, schools, and industry. In agriculture, rats often threaten various agricultural products and crop cultivation. Judging from the aesthetic value, the presence of rats can describe dirty environmental conditions and indicates poor environmental hygiene [2]. In the field of rat health also plays a large impact on human health, rats can be a reservoir of several pathogens that cause disease in humans. Leptospirosis can be caused by rat urine and saliva. The bubonic plague is caused by flea bites that occur in mice. Mice can also transmit several other diseases including murine typhus, salmonellosis, rich psial, rabies, and trichinosis. A zoonotic disease is a disease transmitted by mice or other animals to humans and vice versa. This disease can be fatal if it does not get proper treatment and leads to death [2].

The right environmental conditions make mice breed very quickly. Factors that can support mouse reproduction include the availability of food, drinks, and shelter. Places that have the potential to be found by rats include traditional markets, settlements, and agricultural areas. Mice have a sense of touch, and good hearing so they are classified as intelligent animals because they have a welldeveloped brain, this means mice can learn. The behavior of rats can be determined by instincts and external factors such as temperature, length of the day, rainfall, and previous experience [3]. Paying attention to the rat population is a way of preventing diseases caused by mice. Some of the rats in the tropical residential environment are Rattus tanezumi (house mouse), Rattus norvegicus (sewer rat), and Rattus-rattustanezumitemminh (roof rat) [4].

\section{Materials and Methods}

This type of research used in this research is a descriptive analysis of the data tabulated by the table and described. The variables in this study include locations where mousetraps were laid (bamboo clumps, houses, riverbanks, and gardens). The type of bait used is roasted coconut. The installation of traps is placed at predetermined locations (bamboo clumps, houses, rivers, and seedlings) The installation of traps is carried out in stages from the closest location to the farthest. The installation is carried out in the afternoon at 16.00 WIB (because the rat is active at night) and then the trap is taken the next day between $06.00-08.00$ WIB. The total traps used were 8 traps for 4 location points. The arrests were carried out 10 times in 10 days

The captured mice are labelled based on the day and place of capture. After the trap is taken and the rat is anesthetized with chloroform, the trap is washed and brushed with soap and then dried in the sun before it is used again in the afternoon. The trapped mice were put into plastic which had been given cotton and chloroform. The mice obtained were then identified quantitative and qualitative characters using an identification key that is the Integrated Mouse Pest [5]. 


\section{Results and Discussions}

The condition of the location of the trapping in the Botanical Gardens Liwa, West Lampung is located at an altitude of 800-900 $\mathrm{m}$ above sea level. The weather conditions at the location of the capture include in Table 1.

Table 1: Weather conditions of survey area

\begin{tabular}{|l|c|c|}
\hline Traps location & Humidity (\%) & Temperature $\left({ }^{\circ} \mathbf{C}\right)$ \\
\hline bamboo groves & 79.6 & 20.14 \\
\hline house & 79.6 & 19.93 \\
\hline riverbank & 79.6 & 20.14 \\
\hline garden & 79.6 & 20.14 \\
\hline
\end{tabular}

Identification was carried out directly at the location of the arrest in the Botanical Gardens Liwa, West Lampung. Identification is carried out on the quantitative and qualitative characters of trapped mammals. To study the life of mice, one of them is knowing the species or species of mice that exist, through identification and description. The characteristics of quantitative characters are weight, head-body length, length tail, total length, the width of the auricle, and foot length.

The results of this study were obtained by species of Rattus exulans, Hylomis suillus and Suncus murinus. Data is tabulated in the form of Table 2 as follows.

Table 2: Species and sex of small mammals by trapping location

\begin{tabular}{|c|c|c|c|}
\hline \multirow[t]{2}{*}{ Traps location } & \multirow[t]{2}{*}{ Mammals } & \multicolumn{2}{|c|}{ Number by sex } \\
\hline & & Male & Female \\
\hline House & Suncus murinus & 1 & 2 \\
\hline Garden & Suncus murinus & & 2 \\
\hline Riverbank & Rattus exulans & & 1 \\
\hline \multirow[t]{2}{*}{ Bamboo Groves } & Ratus exulans & 2 & 2 \\
\hline & Hylomis suillus & & 1 \\
\hline \multicolumn{2}{|l|}{ Total } & 3 & 8 \\
\hline
\end{tabular}

This research was conducted every day within 10 days of repetition and 2 days of heavy rain occurred at night, namely on the 4th and 8th day which resulted in no rats being trapped the next morning, but the next day many rats were trapped. The physiological condition of the mammalian body will require more energy when the ambient temperature is high. Weather conditions can affect foraging behavior. These conditions cause rats to starve quickly and need more food, so the mice are lured into traps where there is bait as a food source. Trap-shines are where the nature of rats can adapt to traps so that in the next trapping mice are difficult to catch in the same location shortly. Rats are animals that have a sense of smell and good hearing, and a well-developed brain so that rats can learn from experience [6].

But mice have poor eyesight. Mice are nocturnal animals, at night the mice move in a guided by the hair, a long mustache sensitive to touch. Mice love the sweet smell, especially those from human food. The habit of eating time is at night, rats are not happy in crowded places, for example, 
noisy by the sound of the machine but happy in food storage. Foraging for food is like in the trash, cupboards, sewers, and kitchens.

Rattus exullans have the same appearance as most rats in general, the ability to adapt easily to various environments, from shrubs to forests. Hylomys suillus and Suncus murinus are animals of the order with different families in the Hylomys suillus family Erinaceidae and Suncus murinus soricidae family. Significant differences were seen in the shorter Hylomys suillus tail. This small mammal inhabits the hills and is rarely found in lowland habitats, Hylomys suillus prefers areas with thick vegetation cover to build their nests in bushes. Its prey consists of soft-bodied vertebrates such as earthworms, grubs, and insects. Some differences between rats and shaws are the shape of the snout, the number and arrangement of teeth, the size of the tail, the speed of walking, dirt (faces) and the odor that is generated. Cecurut has a pointed snout, a shorter tail that signifies not being good at climbing, walking slowly, dirt smaller and wet, and a very sharp odor coming from the anal glands around hisanus that serves to defend the body and chase away enemies. Besides the arrangement of teeth, Also, the arrangement of teeth in his mouth is also very different from rats. Rat and shredded feed differed mice ate cereals, fruits, and vegetables, while shrews ate insects (animal protein) both living and dead insects. Cecurut adapt so that these animals have been able to adapt to food other than insects, which are the leftovers of human food as omnivorous animals (eating everything). This type of shaman belongs to the species Suncus murinus (shaman of the house), called shaman of the house because of its habitat in the area of our home.

The type of trap used to trap mice is a single live trap with a length of $35 \mathrm{~cm}$ x width $25 \mathrm{~cm}$ which only has one side of the entrance. The working principle of a single live trap is that the trap door will be closed when the bait is pulled by the rat, and the rat will be trapped. The success of the trap is $34.375 \%$ (Table 3 ). A total of 11 trapped in 10 days. The success rate of trapping in the area can be expected due to the presence of food, water, and bushes as mice nests. Another factor is the location of the trapping adjacent to a river which is a source of water for mice. The success of trapping can be influenced by several factors including the selection of bait (grilled coconut) and the position of laying a trap. The roasted coconut can give off a scent that can attract mice to enter the trap. Mice like roasted coconut, allegedly because roasted coconut has a strong aroma. The success rate of trapping by different locations is presented in Table 3.

Table 3: Capture rate by trapping location

\begin{tabular}{|l|c|c|c|}
\hline Location & Number of traps & Number of captures & Capture rate \\
\hline House & 8 & 5 & $62,5 \%$ \\
\hline Garden & 8 & 3 & $37,5 \%$ \\
\hline Riverbank & 8 & 1 & $12,5 \%$ \\
\hline Bamboo Groves & 8 & 2 & $25 \%$ \\
\hline Total & 32 & 11 & $34,375 \%$ \\
\hline
\end{tabular}

Trap results in different habitats are presented in Table 3 Rattus exullans and Hylomys suillus are more commonly found in bamboo clump habitats, while Suncus murinus is in the habitat of homes and garden yards. Habitat for each species is different, but does not limit the distribution area of species. 
Rats have territorial territory under their control. Observation results indicate that the bamboo clump habitat is a territorial area for the species of Rattus exullans. The number of Rattus exullans is more commonly found in bamboo clumps, it is thought that underneath the surface of the bamboo groves there is a rat's nest due to the smell of urine and the presence of rat droppings, because the habitat of the rats themselves likes to make their nests in the ground covered with bushes. Suncusmurinus is a species that is very adaptable and can live around human habitation, in this study Suncusmurinus was found in several houses in the house as many as 3 animals and in plantations as many as 2 individuals. The results of the capture of riverbanks are relatively the least due to moderate rainfall so that in riverbank areas water often overflows to the surface during heavy rains which results in wet riverbank locations.

Observation of the sex of mice is needed to determine the mobility of mice in the area, physically the sex of mice can be easily seen the difference between males and females. In this study, more female rats were obtained than male rats. According to Priyambodo [2] which states that female rats are more easily captured than male rats because in their group's female mice are individual foraging for their children while male mice play a greater role in protecting their nests or territorial areas. Female mice are more easily caught during the breeding and lactating season because females need large amounts of food [7].

\section{Conclusions and Recommendations}

There are three species of small mammals were caught in the Liwa Botanical Garden, namely others, Rattus exulans, Suncus murinus, and Hylomys suillus. The most mammals were captured at bamboo groves and among the captured mammals female were the most.

\section{Acknowledgements}

The authors are grateful to all managers and staff of the Liwa Botanical Garden for their sincere support so the survey can take place without significant obstacle.

\section{References}

[1] Supriyati Dina, Adil Ustiawan. 2013. Spesies Tikus Cecurut danpinjal yang Ditemukan di Pasar Kota Banjarnegara Kabupaten Banjarnegara Tahun 2013. Balaba, Volume.9, No.02.

[2] Priyambodo, 2003. Pengendalian Hama TikusTerpadu. Jakarta (ID): Penebar Swadaya.

[3] Marbawati, D. Ismanto, H. 2011. Identifikasi tikus (pelatihan di laboratorium mamalia Lembaga Ilmu Pengetahuan Indonesia, Jakarta). Balaba 7 (2): 46- 48.

[4] Rusmini. 2011. Bahaya Leptospirosis (Penyakit Kencing Tikus) \& Cara Pencegahannya. Yogyakarta: Gosyen Publishing.

[5] Priyambodo. 2014. Tikus. Di dalam: Singgih HS danUpik KH, editor. Hama Permukiman Indonesia. Bogor: Unit Kajian Pengendalian Hama Permukiman (UKPHP). hlm 195-212

[6] Astuti, D. R. 2013. Keefektifan rodentisida racun kronis generasi II terhadap keberhasilan penangkapan tikus. J Kemas 8(2): 183-189.

[7] Nasir, M. dan Mahmud, A, H. 2012. Kondisi cuacater hadap peluang menangkap mamalia kecil pada kawasan perkebunan sawit di Kabupaten Nagan Raya Provinsi Aceh. Dalam: Situmorang M, Syamsuardi, Mulya MB, Jatmilah I, Widhiastuti R, Tanjung M, Nurcahya K, editor. Peran Biologi 
dalam Meningkatkan Daya Saing Global. Seminar Nasional Biologi; 2012 Mei 11; Medan, Indonesia. Medan (ID): USU Press. HIm 138-141

\footnotetext{
*Corresponding author.

E-mail address: bemicern4@gmail.com
} 